\title{
Quantification and timing of porosity evolution in tight sand gas reservoirs: an example from the Middle Jurassic Shaximiao Formation, western Sichuan, China
}

\author{
Zheng-Xiang L Lï ${ }^{1}$ Su-Juan $\mathrm{Ye}^{2} \cdot$ Xiang Yang ${ }^{1} \cdot{\text { Rong } \mathrm{Li}^{3} \cdot \text { Yuan-Hua Qing }}^{1,4}$
}

Received: 28 April 2014/Published online: 7 April 2015

(C) The Author(s) 2015. This article is published with open access at Springerlink.com

\begin{abstract}
The diagenesis and porosity evolution of the Middle Jurassic Shaximiao sandstones were analyzed based on petrographic observations, X-ray diffractometry, scanning electron microscopy observations, carbon and oxygen stable isotope geochemistry, fluid inclusion microthermometry, and thermal and burial history modeling results. The point count data show that secondary pores (av. $5.5 \%$ ) are more abundant than primary pores (av. $3.7 \%$ ) and are thus the dominant pore type in the Shaximiao sandstones. Analysis of porosity evolution indicates that alteration of sandstones mainly occurred during two paragenetic stages. Mechanical compaction and cementation by early chlorite, calcite, and quartz typically decrease the depositional porosity $(40.9 \%)$ by an average of $37.2 \%$, leaving porosity of $3.7 \%$ after stage $\mathrm{I}\left(<85{ }^{\circ} \mathrm{C}\right.$, $175-145 \mathrm{Ma}$ ). The original intergranular porosity loss due to compaction is calculated to be $29.3 \%$, suggesting that mechanical compaction is the most significant diagenetic process in primary porosity destruction. Stage II can be further divided into two sub-stages (Stage $\mathrm{II}_{\mathrm{a}}$ and Stage $\left.\mathrm{II}_{\mathrm{b}}\right)$. Stage $\mathrm{II}_{\mathrm{a}}\left(85-120^{\circ} \mathrm{C}, 145-125 \mathrm{Ma}\right)$ is characterized
\end{abstract}

Su-Juan Ye

sujuan_ye@hotmail.com

1 State Key Laboratory of Oil and Gas Reservoir Geology \& Exploitation, Chengdu University of Technology, Chengdu 610059, Sichuan, China

2 Exploration and Production Research Institute, Sinopec Southwest, Chengdu 610041, Sichuan, China

3 Chengdu Institute of Geology and Mineral Resources, Chengdu 610081, Sichuan, China

4 PetroChina Tarim Oilfield Company, Korla 841000, Xinjiang, China

Edited by Jie Hao by late dissolution, which enhanced porosity by $8.8 \%$, and the porosity increased from $3.7 \%$ to $12.5 \%$. During stage $\mathrm{II}_{\mathrm{b}}\left(>120{ }^{\circ} \mathrm{C}, 125-0 \mathrm{Ma}\right)$, the precipitation of late chlorite, calcite, quartz, and kaolinite destroyed $3.3 \%$ porosity, leaving porosity of $9.2 \%$ in the rock today.

Keywords Diagenesis - Porosity evolution .

Tight gas sandstones · Jurassic · Western Sichuan

\section{Introduction}

Reservoir quality is one of the key controls on prospectivity during petroleum exploration and exploitation. With the development of experimental methods, petroleum scientists have become more concerned about quantification and timing of porosity evolution, water-rock-hydrocarbon interaction, diagenetic kinetics, multi-scale evaluation of diagenesis, retention diagenesis, and reservoir quality prediction (Wood and Byres 1994; Bjфrlykke and Jahren 2012; Taylor et al. 2004, 2010; Ajdukiewicz and Lander 2010). Due to the increasing market demand for gas and also to technology advances, tight gas plays have received considerable attention in recent years, and it is now important from both a scientific and a practical standpoint to investigate diagenesis in these low permeability sandstones (Stroker et al. 2013). However, the diagenesis and reservoir quality evolution pathways in tight gas sand reservoirs are more complex than those in conventional reservoirs, and so qualitative analysis and inference-based quantitative study cannot provide satisfactory results. In order to quantitatively predict reservoir quality, numerical simulations of diagenetic processes have been carried out by some researchers (Prodanović et al. 2013; Dai et al. 2003; Liu et al. 2014), and many critical concerns, including the selection 
of diagenetic environment parameters, the quantitative calibration of various diagenetic processes, and the delimitation of diagenetic time, present great challenges to diagenesis and reservoir quality research. Studies in tectonics, stratigraphy/sedimentology, geochemistry, and burial-thermal history should be combined together to achieve integrated research (Zhang et al. 2013). In other words, what are the temporal and spatial relationships, both relative and absolute, among different diagenetic reactions and what controls reservoir quality?

The Middle Jurassic Shaximiao Formation in western Sichuan, China is such a reservoir, which contains sandstones with $50 \%$ of samples having porosity lower than $8 \%$ and permeability less than $0.1 \mathrm{mD}$ and was previously regarded as tight sandstones with no gas storage and flow capacity. However, commercial gas flows have been obtained from the Shaximiao Formation with high-yield gas flows produced from many wells, demonstrating its significant gas reserve and production potential. The Shaximiao sandstones have been deeply buried with maximum depths $>3.5 \mathrm{~km}$ and have undergone complex diagenetic alternations, which thus cause the sandstones to be tight and highly heterogeneous. Previously, studies of the Shaximiao sandstones have mainly focused on investigating the overall reservoir characteristics, including depositional systems (Tan et al. 2008; Wang and Wang 2010; Ye and Lü 2010; Yang et al. 2012), petrology, diagenetic processes, and reservoir classification and evaluation (Lü et al. 2000; Ye and Lü 2010; Yang et al. 2012). However, the dominant pore types and the temporal relationship between hydrocarbon emplacement and porosity evolution have not been well investigated previously due to the absence of studies on quantification and timing of porosity evolution. In order to well understand the mechanism of hydrocarbon accumulation and predict hydrocarbon-enriched zones, quantifying the spatial and temporal distribution of diagenetic alternations and of porosity is of significant importance.

The main objectives of this study are to analyze diagenetic modifications quantitatively, to estimate the volume of secondary pores and recognize the importance of dissolution pores, to determine the timing of important diagenetic processes that altered the petrophysical properties of the sandstones using a wide range of techniques, including petrography, fluid inclusion and isotopic studies, and thermal history modeling, and to establish porosity evolution through time and relate the porosity to each critical moment, especially to the timing of hydrocarbon emplacement.

\section{Geological setting}

The western Sichuan depression is located in the western part of the Sichuan Basin and structurally bounded by the Longmen Mountain thrust belt to the west and by the
Qinling orogenic belt to the north (Meng et al. 2005) (Fig. 1). It underwent multi-stage tectonic movements from the Mesozoic, including Indosinian, Yanshanian, and Himalayan orogeny (Yang et al. 2012).

The western Sichuan depression contains numerous commercial gas accumulations in mainly Mesozoic reservoirs. More than ten tight gas sand fields have been discovered to date in this area. The Upper Triassic to Quaternary sediments deposited in western Sichuan are dominated by siliciclastic rocks of offshore marine to terrestrial origin with the thickness up to $8 \mathrm{~km}$ (Gu and Liu 1997; Xu et al. 1997; Yang et al. 2012).

The Middle Jurassic Shaximiao Formation is 600-750m thick. It overlies the Middle Jurassic Qianfoya Formation and underlies the Upper Jurassic Suining Formation (Fig. 2). The Shaximiao Formation comprises interbedded siltstone and sandstone, interpreted as fluvial and lacustrine-deltaic deposits (Tan et al. 2008; Wang and Wang 2010; Ye and Lü 2010; Yang et al. 2012).

Most of the hydrocarbons in the Shaximiao Formation are thought to have been generated from the 5 th member of the Xujiahe Formation $\left(\mathrm{T}_{3} x^{5}\right)$, and the time of peak hydrocarbon generation and migration was the late Early Cretaceous (100 Ma) (Cai and Liao 2000; Qin et al. 2007; Shen et al. 2008).

\section{Samples and method}

A total of 1225 core samples were selected from the Shaximiao Formation from 32 exploration wells. Thin sections were prepared for all samples using blue/red-dyed epoxy impregnation. Thin-section petrography was used to determine whole rock mineralogy, diagenetic relationships, porosity characteristics, and clay growth occurrence and habits in the pore space. The modal composition and porosity of 132 representative samples were obtained by counting 300 points in each thin section. Representative samples were viewed under a scanning electron microscope (SEM) equipped with an energy dispersive X-ray spectrometer (EDX) and cathodoluminescence imaging.

Pores were separated into residual primary intergranular pores, intragranular dissolution pores, and enlarged intergranular dissolution pores during the point counting of each thin section used in this study. Residual primary intergranular pores tend to be of straight-angular cross section and can thus be identified easily. However, it is difficult to estimate the proportion of secondary pores since enlarged intergranular dissolution pores include both primary and secondary pores. After obtaining the average volume of residual primary intergranular pores and intergranular dissolution pores based on point counts, the secondary contribution to the intergranular dissolution 
Fig. 1 Location map and tectonic elements of the Sichuan Basin (simplified from Meng et al. 2005)

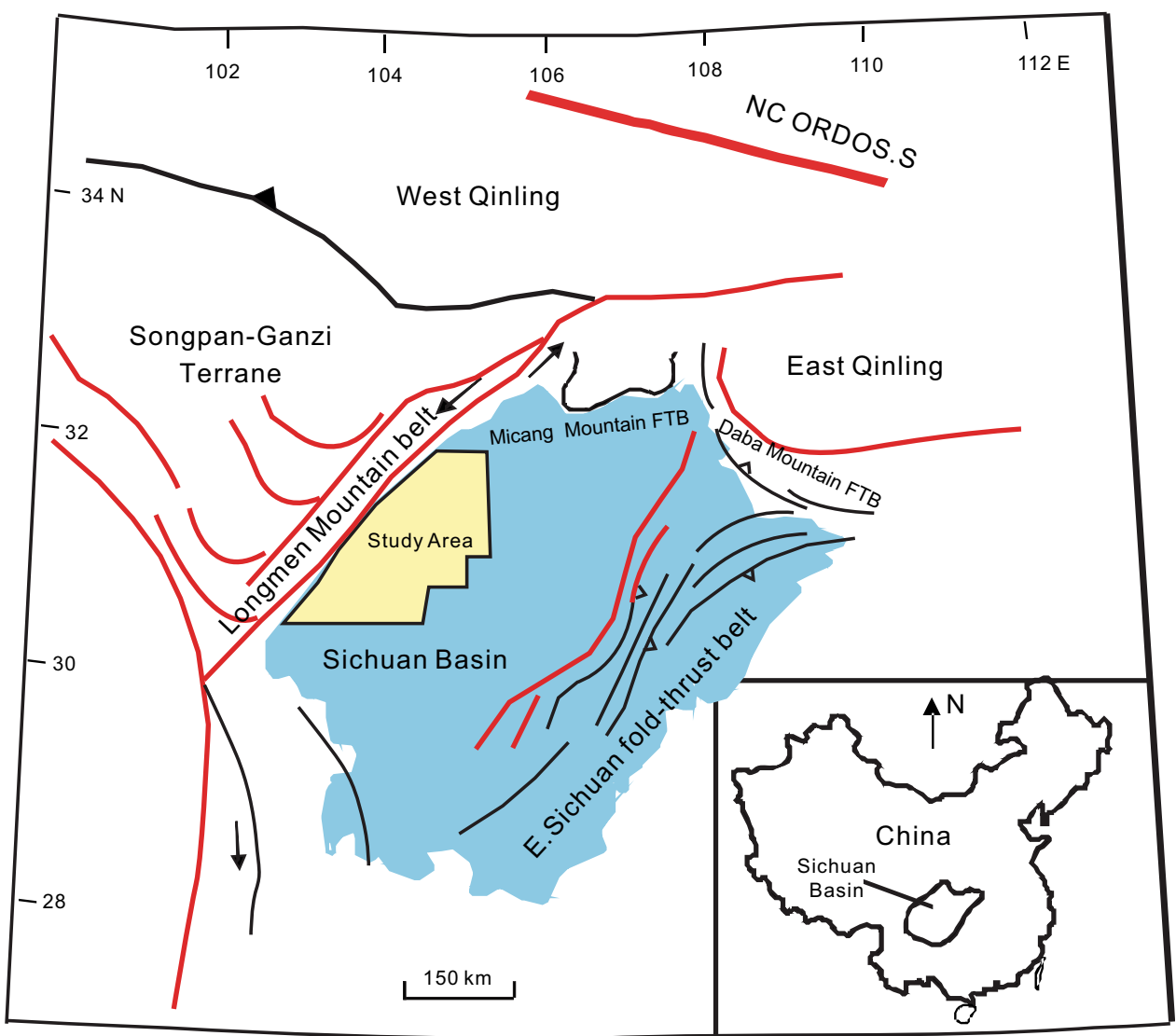

\begin{tabular}{|c|c|c|c|c|c|c|}
\hline System & Series & \multicolumn{3}{|l|}{ Formation } & Age, $\mathrm{Ma}$ & Hydrocarbon \\
\hline \multicolumn{5}{|l|}{ Cretaceous } & \multirow{8}{*}{$\begin{array}{l}144 \\
154\end{array}$} & \\
\hline \multirow{6}{*}{ Jurassic } & \multirow{2}{*}{ Upper } & \multicolumn{2}{|c|}{ Penglaizhen } & $\mathrm{J}_{3} p$ & & - \\
\hline & & \multicolumn{2}{|l|}{ Suining } & $\mathrm{J}_{3} s n$ & & $\bullet$ \\
\hline & \multirow{3}{*}{ Middle } & \multirow{2}{*}{ Shaximiao } & Upper & $\mathrm{J}_{2} S$ & & $\bullet$ \\
\hline & & & Lower & $\mathrm{J}_{2} x$ & & - \\
\hline & & \multicolumn{2}{|l|}{ Qianfoya } & $\mathrm{J}_{2} q$ & & \\
\hline & Lower & \multicolumn{2}{|l|}{ Baitianba } & $\mathrm{J}_{1} b$ & & \\
\hline Triassic & Upper & \multicolumn{2}{|l|}{ Xujiahe } & $\mathrm{T}_{3} x$ & & - \\
\hline
\end{tabular}

Fig. 2 Triassic to Cretaceous stratigraphic framework of the western Sichuan (adapted from Yang et al. 2012) porosity was estimated as the difference between average enlarged intergranular dissolution porosity and average residual primary intergranular porosity.

In situ carbon and oxygen isotope analysis was performed using an Nd:YAG laser microprobe. Laser probe micro-sampling of $\mathrm{C}$ and $\mathrm{O}$ from carbonate cements for isotopic analysis was achieved by focusing a laser beam with a wavelength of $1064 \mathrm{~nm}$ and a diameter of $20 \mu \mathrm{m}$ onto a sample situated in a vacuum chamber to ablate a small area on the sample and liberate $\mathrm{CO}_{2}$ gas. After purification, the $\mathrm{CO}_{2}$ gas was led directly into a Finnigan MAT 252 mass spectrometer for isotopic analysis.

The temperature for calcite precipitation was calculated using the fractionation equation of Friedman and O'Neil (1977):

$$
\begin{aligned}
1000 \times \ln \alpha_{\text {calcite-water }}= & 2.78 \times 10^{6} \times T^{-2} \\
& -2.89(\mathrm{SMOW}) \\
\alpha_{\text {calcite-water }}=(1000+ & \left.\delta^{18} \mathrm{O}_{\text {calcite }}\right) /\left(1000+\delta^{18} \mathrm{O}_{\text {water }}\right)
\end{aligned}
$$


Fourteen thick double-side polished thin sections were prepared for microthermometric measurements. Homogenization temperatures were measured using a Linkam THMS-600 heating/cooling stage. Only primary fluid inclusions with both aqueous and hydrocarbon phases were selected from authigenic quartz to determine their minimum precipitation temperatures (Liu et al. 2005; Lu and Guo 2000; Marfil et al. 2000).

$\mathrm{X}$-ray diffraction (XRD) analyses were carried out on twenty-two bulk samples and $<2 \mu \mathrm{m}$ size fractions, which permitted quantification of quartz, feldspar, calcite, and clay contents.

The burial-thermal history was constructed using Schlumberger PetroMod 11 software. Input data included age, thickness, and lithology of stratigraphic units in the study area. The heat-flow model was developed based on knowledge of the tectonic history of the basin and calibrated against available vitrinite reflectance $\left(R_{\mathrm{o}}\right)$ data. The estimate of erosion was verified using two independent burial history techniques: sonic velocity and vitrinite reflectance (Shen et al. 2011).

\section{Results}

\subsection{Sandstone petrology}

The Shaximiao sandstones are generally well sorted, with a fine to medium grain size. Sandstones are mostly lithic arkoses (sample proportion: 59\%) and feldspathic litharenites (sample proportion: 19\%) (Fig. 3). Quartz is the predominant framework component in the sandstones, usually constituting $45 \%-55 \%$ of the whole rock volume with an average framework composition of $\mathrm{Q}_{51} \mathrm{~F}_{28} \mathrm{R}_{21}$. Plagioclase dominates over K-feldspar (Table 1). Rock fragments are sedimentary, metamorphic, and volcanic in origin. The detrital composition of sandstones varies with different provenance (Ye and Lü 2010). The sediments in the western region of depression were mainly sourced from the middle segment of Longmen Mountain and are mostly litharenites. The deposits in the middle and eastern parts were supplied from Micang Mountain and Daba Mountain and are generally sandstones with a high feldspar content.

Authigenic minerals comprise calcite, authigenic quartz, illite, chlorite, and kaolinite (Table 1). According to the point count data, cement volume ranges from $4.4 \%$ to $28.7 \%$, with an average of $11.2 \%$ (Table 2).

\subsection{Diagenesis}

The Shaximiao sandstones in western Sichuan are strongly influenced by mechanical compaction, cementation, and

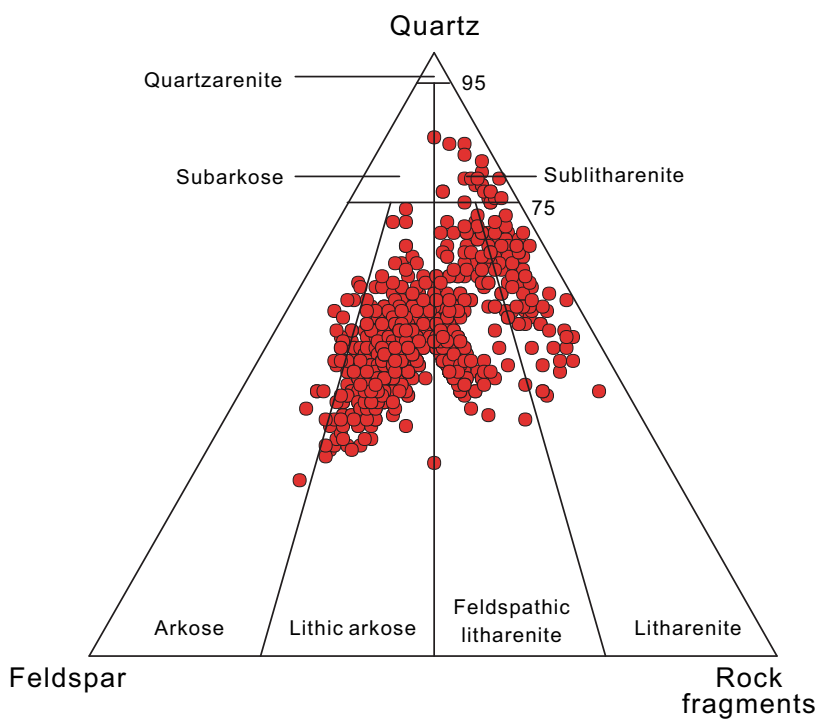

Fig. 3 Detrital compositions of the Shaximiao sandstones (nomenclature according to Folk's classification scheme, 1974)

Table 1 Statistical summary of XRD results (absolute values \%)

\begin{tabular}{lllrr}
\hline & Minimum & Maximum & Mean & SD \\
\hline Quartz & 19 & 66 & 42.0 & 13.0 \\
Plagioclase & 5 & 64 & 38.0 & 15.9 \\
K-feldspar & 0 & 11 & 2.1 & 3.0 \\
Clay & 8 & 33 & 14.1 & 5.5 \\
Calcite & 0 & 18 & 3.8 & 4.3 \\
Dolomite & 0 & 1 & 0.1 & 0.3 \\
Illite & 0.4 & 14.5 & 2.4 & 3.0 \\
Kaolinite & 0 & 6.3 & 2.5 & 2.1 \\
Chlorite & 1.5 & 10.6 & 4.6 & 2.5 \\
\hline
\end{tabular}

dissolution. Cementation was mainly by calcite, authigenic quartz, and clay minerals.

The sandstones had suffered a moderate degree of compaction, which is evidenced by rearrangement of detrital grains, squeezing of ductile grains, and the presence of straight contacts.

Diagenetic clay minerals include chlorite, kaolinite, and illite (Tables 1,2). Chlorite is common in sandstones and occurs mainly in two forms: grain-coating (pore-lining) and pore-filling. SEM imaging indicates that grain-coating chlorites are made of thin and finely crystalline aggregates (thickness: $0.008-0.02 \mathrm{~mm}$ ) perpendicularly to grain surfaces (Fig. 4a, c, d, f). Pore-filling chlorite typically consists of pseudohexagonal platelets and occurred after graincoating chlorite (Fig. 4a, b, f). Kaolinite constitutes a trace to $57 \%$ of the clay fraction in the sandstones and appears mostly as loose, micro-porous booklets (Fig. 4b). The 
Table 2 Average values for the point-count authigenic minerals $(\%)$

\begin{tabular}{|c|c|c|c|c|c|c|c|}
\hline \multicolumn{2}{|c|}{ Authigenic quartz } & \multicolumn{2}{|c|}{ Calcite } & \multicolumn{2}{|l|}{ Chlorite } & \multirow[t]{2}{*}{ Kaolinite } & \multirow[t]{2}{*}{ Total } \\
\hline Early & Late & Early & Late & Grain-coating & Pore-filling & & \\
\hline 1.7 & 0.8 & 1.7 & 1.0 & 4.5 & 1.0 & 0.5 & 11.2 \\
\hline
\end{tabular}
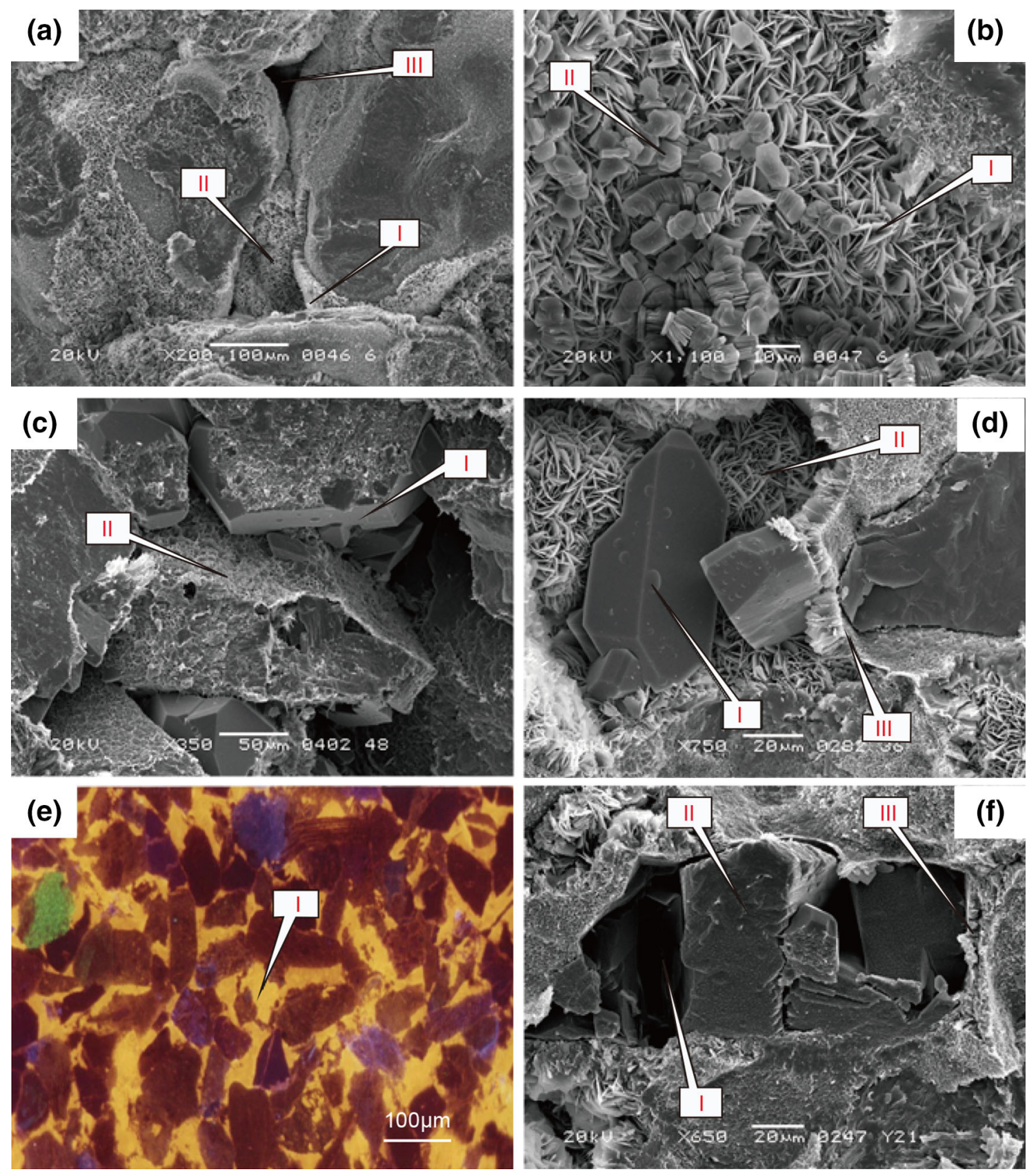

Fig. 4 Optical and SEM images of a grain-coating chlorite (I) occurred before pore-filling chlorite (II) and both partly filled primary intergranular pores (III) (Well CJ619, $2461.2 \mathrm{~m}$ ). b Kaolinite (II) grew on pore-filling chlorite (I) (Well CJ619, 2461.2 m). c Quartz overgrowing (I) was developed from a quartz surface where grain-coating chlorite (II) was absent (Well CX605, $2824.34 \mathrm{~m}$ ). d Authigenic quartz (I) grew on pore-filling chlorite (II); residual grain-coating chlorite is shown as III (Well GM31, $2587.34 \mathrm{~m}$ ). e Cathodoluminescence image of early framework-stabilizing calcite (I) (Well CX168, $2332.70 \mathrm{~m}$ ). f Calcite (II) partially filled secondary pores (I); remaining chlorite coating is shown as III (Well GJ6, $2819.41 \mathrm{~m}$ ) 
kaolinite cement typically has a fresh appearance and postdates the authigenic quartz and chlorite (Fig. 4b). Fibrous illite is observed by SEM in many samples (trace to $14.5 \%$, av. $2.4 \%$ ).

Quartz cement (trace to $4 \%$, av. $2.5 \%$ ) occurs as syntaxial overgrowths on detrital quartz and as euhedral quartz (Fig. 4c, d). The average volume of early quartz overgrowths is relatively more than that of later euhedral overgrowths and outgrowths (Table 2).

Carbonate cements mainly include calcite and minor amounts of dolomite (Table 1). Calcite cement varies in abundance from trace to $20 \%$ with an average of $2.7 \%$ (Table 2). There are two forms of calcite: early diagenetic framework-stabilizing calcite (Type I) and late sparry calcite (Type II). Type I calcite fills intergranular pores and displays evidence of moderate to pervasive recrystallization into coarse, blocky calcite (Fig. 4e). The grained enclosed Type I calcite is loosely packed and shows no authigenic chlorite, indicating that it is the earliest formed authigenic mineral. Type II calcite fills intergranular secondary pores (Fig. 4f) and replaces feldspar and rock fragments. Type II calcite engulfs and thus post-dates quartz overgrowths and chlorite.

The dissolution of feldspar (mainly plagioclase) and early calcite cement is common in sandstones (Fig. 5). Feldspar dissolution has resulted in oversized and moldic pores which contain corroded remnants of feldspar. Partial dissolution of rock fragments has resulted in the formation of intragranular pores. Late authigenic quartz, calcite, and

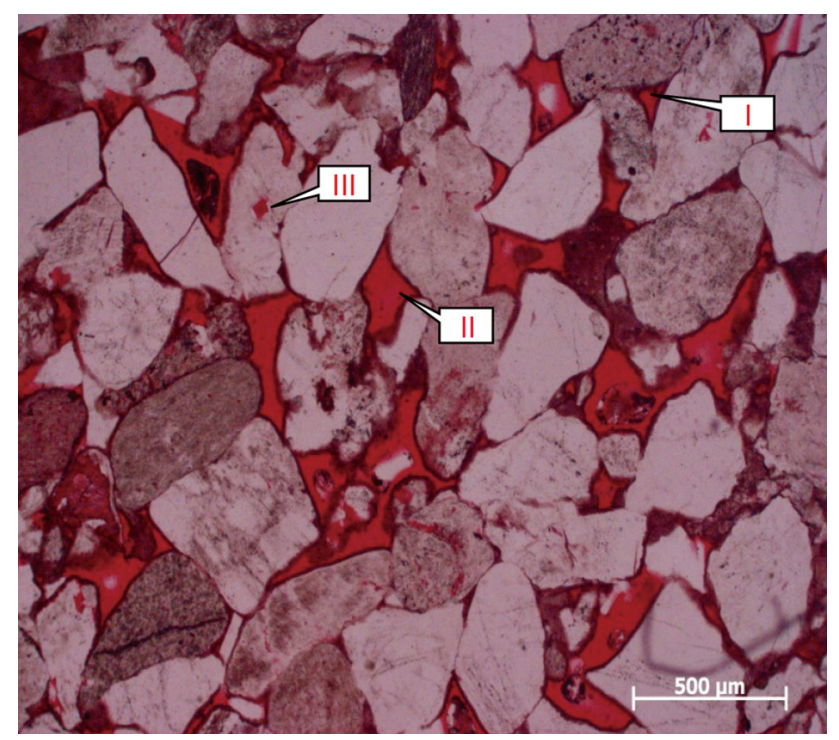

Fig. 5 Plane-polarized light thin-section photomicrograph showing primary intergranular pores (I), enlarged intergranular dissolution pores (II), and intragranular dissolution pores (III) (Well GM31, $2719.95 \mathrm{~m}$ ) kaolinite cements are interpreted to partially fill secondary porosity.

\subsection{Quantity of dissolution pores}

Quantification of the percentage of primary and secondary porosity is of great significance since it determines which factors or processes have the greatest impact on porosity. The Shaximiao sandstones contain primary intergranular porosity and secondary porosity (Fig. 5). The overall coreplug and thin-section porosity values range from $4.4 \%$ $17.1 \%$ (av. $11.1 \%$ ) to $4.4 \%-20.2 \%$ (av. 9.2\%), respectively (Table 3 ). The difference of about $1.8 \%$ between core-plug and thin-section porosity values is attributed to the presence of micro-porosity within clay minerals.

Based on point count data, the percentage and contribution of primary/secondary pores to total visible porosity were calculated (Table 3), indicating that secondary pores are more abundant than primary pores (av. $5.5 \%$ and $3.7 \%$, respectively), and most of samples are dominated by secondary pores.

\subsection{Temperature of quartz cementation}

Forty-seven homogenization temperatures $\left(T_{\mathrm{h}}\right)$ were measured in inclusions located at quartz grain-overgrowth boundaries. These inclusions have been termed Q1. They occur along the "dust-rims", delineating the surfaces of the detrital grains. The overall range of $T_{\mathrm{h}}$ in $\mathrm{Q} 1$ inclusions is $80-95{ }^{\circ} \mathrm{C}$ with an average of $85^{\circ} \mathrm{C}$, suggesting that significant quartz cementation started at around $80^{\circ} \mathrm{C}$ (Fig. 6).

Seventy homogenization temperatures correspond to inclusions located in quartz outgrowths (termed as Q2) and range between 125 and $140{ }^{\circ} \mathrm{C}$ with an average of $130{ }^{\circ} \mathrm{C}$ (Fig. 6).

Table 3 Statistical summary of the point-count primary and secondary porosity $(\%)$ and total thin-section and core-plug porosity (\%)

\begin{tabular}{lllrr}
\hline & Minimum & Maximum & Mean & SD \\
\hline $\begin{array}{lllrr}\text { Primary porosity } \\
\text { Percent }\end{array}$ & 0.5 & 10.0 & 3.7 & 1.6 \\
Contribution & 9.8 & 70.0 & 40.4 & 14.1 \\
Secondary porosity & & & & \\
Percent & 1.8 & 12.5 & 5.5 & 2.2 \\
Contribution & 30 & 90.2 & 59.5 & 14.1 \\
Total thin-section porosity & 4.4 & 20.2 & 9.2 & 2.9 \\
Total core-plug porosity & 4.4 & 17.1 & 11.1 & 2.6 \\
\hline
\end{tabular}

From 132 samples 


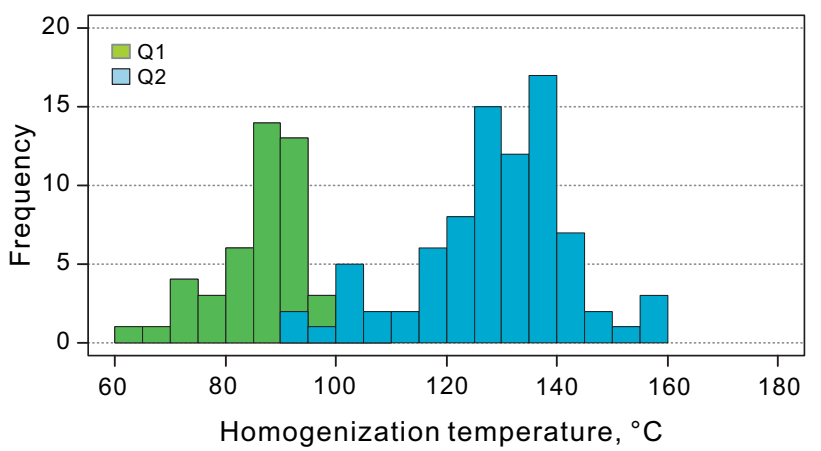

Fig. 6 Homogenization temperatures for 117 fluid inclusions in authigenic quartz cements

\subsection{Temperature of calcite cementation}

The oxygen isotope compositions of carbonates are widely used in paleothermometry (Friedman and O'Neil 1977; Gabitov et al. 2012; Zheng 2011).

The $\delta^{13} \mathrm{C}$ and $\delta^{18} \mathrm{O}$ values of calcite cements are listed in Table 4. The $\delta^{13} \mathrm{C}$ values vary between -5.49 and $-12.62 \%$ with an average of $-8.7 \%$. The $\delta^{18} \mathrm{O}$ values range from -15.39 to $-16.84 \%$, and the $\delta^{18} \mathrm{O}$ values of Type I calcite are very similar to those of Type II calcite (Table 4).

The Shaximiao sandstones were deposited under semiarid and warm conditions (Wang and Wang 2010), and the $\delta^{18} \mathrm{O}_{\mathrm{SMOW}}$ value of $-8 \%$ was assumed for early diagenetic formation water based on the results of Zhang et al. (2008). The current $\delta^{18} \mathrm{O}_{\text {SMOW }}$ formation water composition ( $-4 \%$ ) (Shen et al. 2010; Li et al. 2008) was assumed for late diagenetic formation water. Using the fractionation equation of Friedman and O'Neil (1977), the temperatures for Type I and Type II calcite precipitation would be around 55-59 and $86-97{ }^{\circ} \mathrm{C}$, respectively.

\subsection{Burial and thermal history}

In order to convert temperature and depth to time and thus date when various authigenic minerals precipitated, we have modeled the burial and thermal history in the study area. The modeling results shown in Fig. 7 indicate that the burial history of the Jurassic and Triassic sequences was characterized by an initial period of moderate to rapid subsidence from the Late Triassic to Late Jurassic (210-144 Ma). This was followed by a period of slow subsidence from Late Jurassic to Eocene (144-65 Ma). The subsidence phase was followed by uplift and erosion of $1000-2000 \mathrm{~m}$ of the sedimentary strata from Eocene to Neogene (65-5 Ma). Erosion estimates are based on sonic velocity and vitrinite reflectance (Shen et al. 2011).

\section{Discussion}

\subsection{Paragenetic sequence}

The Shaximiao sandstones have undergone complex diagenetic modifications. Petrographic examination allowed the relative timing of the main diagenetic events to be reconstructed (Fig. 8) and their influence on reservoir porosity to be also evaluated.

Grain-coating chlorite is poorly developed when grains are covered with early calcite cement. Quartz overgrowths were preferably developed where pore-lining chlorites are discontinuous or absent (Fig. 4c), indicating that chlorite coating formed before quartz overgrowth. Chlorite coating pre-dates quartz overgrowth, Type II calcite, and porefilling chlorite (Fig. 4a, d) and is absent along the intergranular straight contacts (Fig. 5), showing that sandstones have undergone mechanical compaction to a lesser extent. $\mathrm{Fe}$ and $\mathrm{Mg}$ ions required for the formation of authigenic chlorite were supplied by the alteration and dissolution of volcanic rock fragments, which are fairly common in the Shaximiao sandstones.

Authigenic quartz occurs as syntaxial overgrowths (Fig. 4c) and outgrowths (Fig. 4d). Quartz overgrowths are posterior to pore-lining chlorite authigenesis and pre-date pore-filling chlorite, whereas quartz outgrowths partially fill primary/secondary intergranular spaces and precipitated after pore-filling chlorite and before Type II calcite
Table 4 Isotopic compositions of calcite cements

\begin{tabular}{lllll}
\hline Sample number & Description & $\delta^{13} \mathrm{C}_{\mathrm{PDB}}, \% 0$ & $\delta^{18} \mathrm{O}_{\mathrm{PDB}}, \% \mathrm{o}$ & Temperature, ${ }^{\circ} \mathrm{C}$ \\
\hline $370-11$ & Type I & -9.96 & -15.45 & 55.6 \\
$168-58$ & Type I & -8.08 & -15.39 & 55.2 \\
$168-68$ & Type I & -9.17 & -16.02 & 59.4 \\
$168-11$ & Type II & -7.55 & -16.84 & 97.0 \\
$168-39$ & Type II & -7.63 & -16.34 & 92.4 \\
$168-97$ & Type II & -12.62 & -16.19 & 91.1 \\
$168-118$ & Type II & -9.1 & -15.6 & 86.0 \\
$167-3$ & Type II & -5.49 & -16.06 & 90.0
\end{tabular}


Fig. 7 Burial and thermal history of the study area. The heat-flow model was developed based on knowledge of the tectonic history of the basin and calibration to maturity data by comparing the $R_{\mathrm{o}}$ calibration data to the calculated values obtained using the Easy\% $R_{\mathrm{o}}$ algorithm of Sweeney and Burnham (1990)
Sweeney and Burnham (1990)_EASY\% $R_{0}=1.0,2.0,3.0\left[\% R_{0}\right]$

Temperature $=50.0,100.0,150.0,200.0\left[{ }^{\circ} \mathrm{C}\right]$

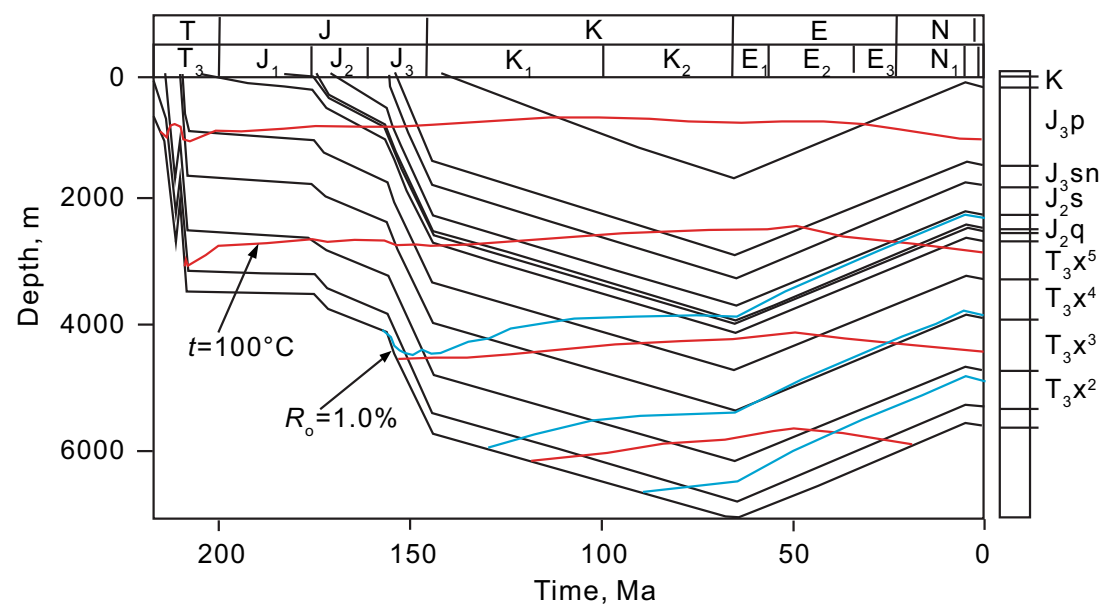

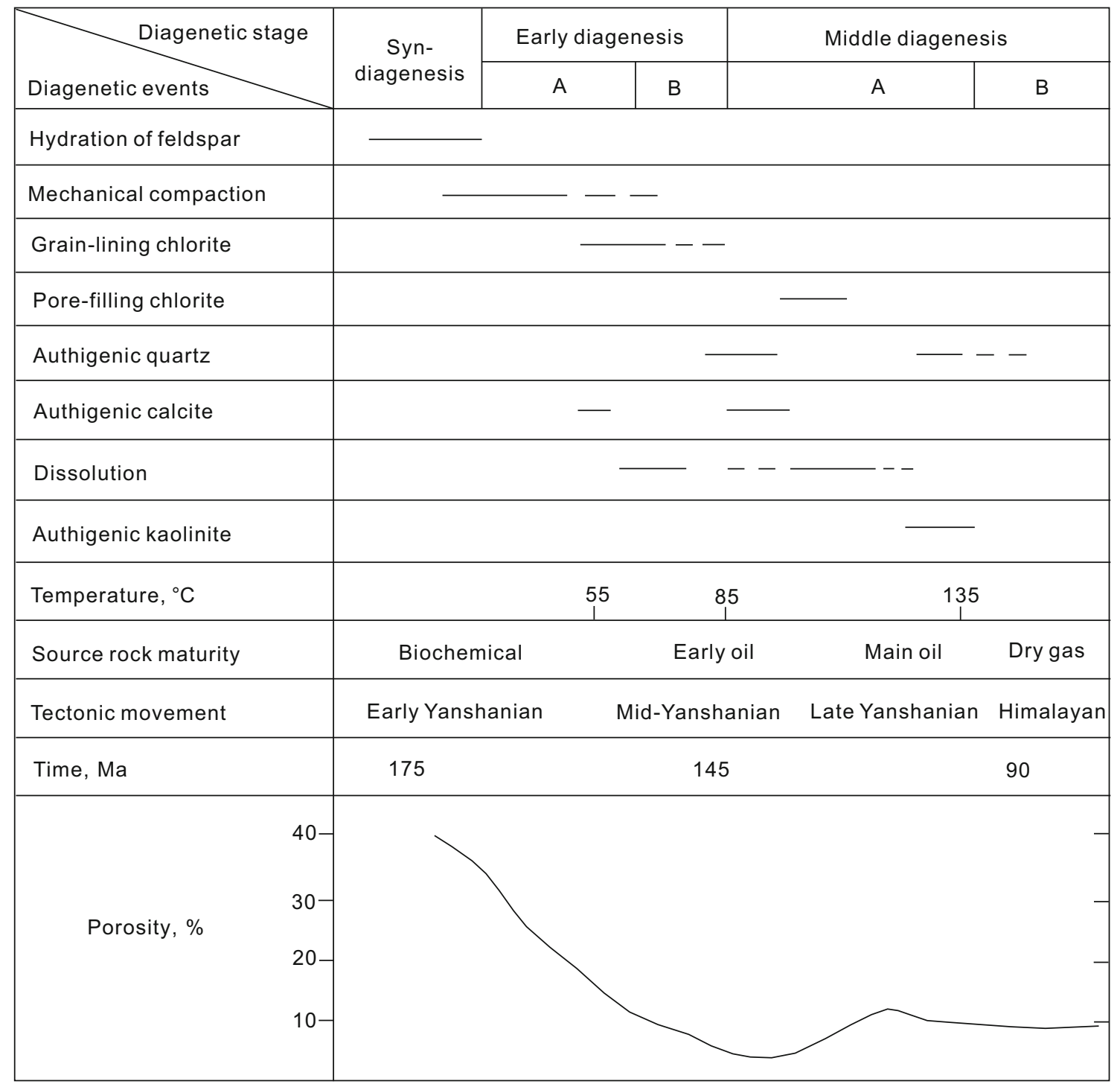

Fig. 8 Paragenetic sequence and porosity evolution history of the Shaximiao sandstones 
(Fig. 4d). Sources of silica include reaction of smectite to illite and dissolution of detrital feldspar minerals.

Type I calcite precipitated as concretionary masses during earliest diagenesis $\left(55^{\circ} \mathrm{C}, 150 \mathrm{Ma}\right.$, Fig. 4e), and some samples display limited mechanical compaction due to early calcite cementation. Type II calcite fills dissolution pores (Fig. 4f), indicating that its precipitation was synchronous with or after late dissolution.

Detrital feldspars have undergone partial dissolution during eogenetic and mesogenetic stages. Remaining chlorite coating in early dissolution pores is generally deformed and exhibits vermiform structure, indicating that eogenetic dissolution pores were destroyed by subsequent compaction. However, remaining chlorite coating in late dissolution pores shows no deformation, demonstrating that no mechanical compaction occurred after late dissolution (Fig. 4f).

\subsection{Porosity evolution}

Alteration of sandstones mainly occurred during two paragenetic stages. Stage I is characterized by mechanical compaction and precipitation of early quartz, calcite, and chlorite. Stage II is characterized by dissolution and infilling of secondary pore spaces (Fig. 8).

\subsubsection{Original porosity}

The depositional porosity in sandstones was generally assumed to be $40 \%$ (Houseknecht 1987). However, it has been demonstrated that original porosity is strongly influenced by depositional environment (Beard and Weyl 1973; Bloch and McGowen 1994). In this study, the original porosity was estimated using the empirical formula proposed by Beard and Weyl (1973).

$$
\begin{aligned}
& \text { Original porosity (OP) } \\
& \quad=20.91+22.9 \text { /Trask's sorting coefficient (So) }
\end{aligned}
$$

Trask's sorting coefficients for four sets of the Shaximiao reservoirs are $1.125,1.13,1.13$, and 1.218, respectively. Thus, the original porosities were calculated to be $41.3 \%, 41.2 \%, 41.2 \%$, and $39.7 \%$, respectively, with an average of $40.9 \%$.

\subsubsection{Stage $I\left(<85^{\circ} \mathrm{C}, 175-145 \mathrm{Ma}\right)$}

Diagenetic alternations during Stage I include mechanical compaction and cementation by early quartz, calcite, and chlorite. Secondary pores formed by early dissolution were generally destroyed by continued compaction, and thus this process is not taken into account in this study.
Houseknecht (1987) and Ehrenberg (1989, 1995) developed a quantitative approach based on point count data to compute the original intergranular porosity loss due to compaction (COPL) and cementation (CEPL). However, the equations of Houseknecht (1987) and Ehrenberg (1989) assume that the secondary porosity and post-dissolution cement volumes are $0 \%$, which could cause COPL to be under-estimated if this assumption is far from reality. As discussed above, mechanical compaction has no or little impact on the Shaximiao sandstones after late dissolution. Thus, residual primary porosity (RPP) and pre-dissolution cement volumes (VEC) should be used for the calculation of COPL:

$\mathrm{COPL}=\mathrm{OP}-\mathrm{RPP}-\mathrm{VEC}$

where COPL is the original intergranular porosity loss due to compaction (\%), OP is original porosity (\%), RPP is residual primary porosity $(\%)$, and VEC is the total volume of early diagenetic cements $(\%)$.

During this stage, primary porosity was reduced from $40.9 \%$ to $3.7 \%$ by mechanical compaction and early diagenetic cementation through precipitation of quartz $(1.7 \%)$, calcite $(1.7 \%)$, and grain-coating chlorite $(4.5 \%)$ (Table 2; Fig. 8). Based on Eq. (4), COPL is then calculated to be $29.3 \%$. This suggests that mechanical compaction is a major factor of the loss of primary pores (Fig. 9), which is in good agreement with the rapid subsidence during this period (Fig. 7).

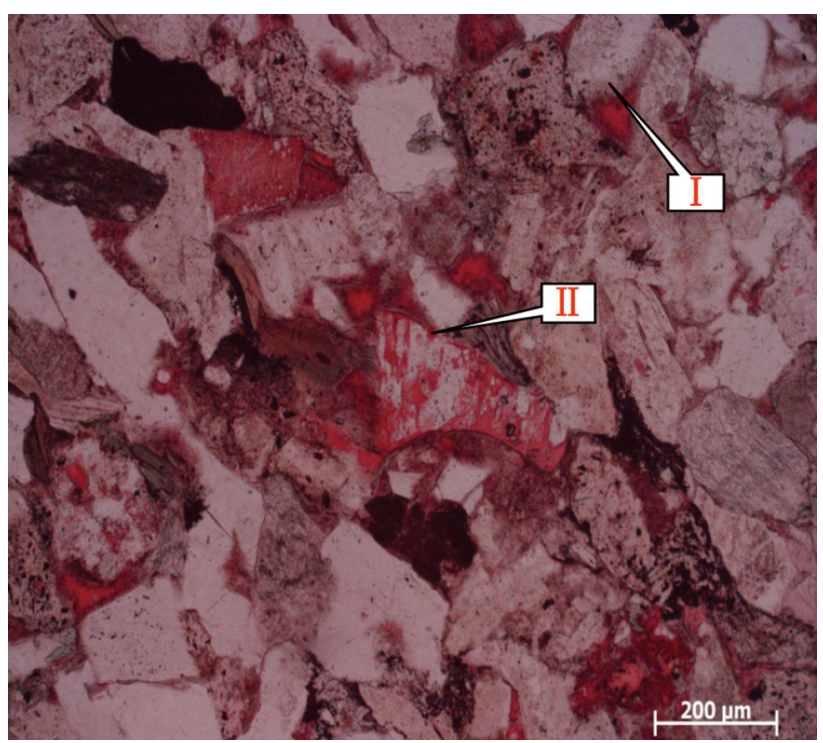

Fig. 9 Photomicrograph of remaining primary pore (I) and intragranular dissolution pore (II). Primary pores have been lost mainly by mechanical compaction. Well JS7, $1954.9 \mathrm{~m}$ 


\subsubsection{Stage II $\left(>85^{\circ} \mathrm{C}, 145-0 \mathrm{Ma}\right)$}

This stage corresponds to a middle diagenetic stage and can be further divided into two sub-stages (Stage $\mathrm{II}_{\mathrm{a}}$ and Stage $\left.\mathrm{II}_{\mathrm{b}}\right)$. Stage $\mathrm{II}_{\mathrm{a}}\left(85-120^{\circ} \mathrm{C}, 145-125 \mathrm{Ma}\right)$ is dominated by late dissolution. Secondary pores formed in this stage by feldspar dissolution, and the source of acidic fluids is through the maturation of $\mathrm{T}_{3} x^{5}$ source rocks. Organic acidenriched fluids migrated upwards along faults and resulted in the formation of secondary pores in the Shaximiao sandstones. During stage $\mathrm{II}_{\mathrm{b}}\left(>120^{\circ} \mathrm{C}, 125-0 \mathrm{Ma}\right)$, the dissolution pores were partially filled by late chlorite, quartz, calcite, and kaolinite cement (Table 2), leaving a residual secondary porosity of $5.5 \%$ (Table 3 ). The total secondary porosity (TSP) formed during this period can be approximated as

$\mathrm{TSP}=\mathrm{RSP}+\mathrm{VLC}$

where TSP is the total secondary porosity (\%), RSP is residual secondary porosity observed (\%), and VLC is the total volume of late cements (\%).

According to the point-count data, the volumes of late chlorite, quartz, calcite, and kaolinite are $1 \%, 0.8 \%, 1 \%$, and $0.5 \%$, respectively. Based on Eq. (5), the total secondary porosity is thus calculated to be $8.8 \%$.

It has widely been assumed that oil emplacement will retard the precipitation of quartz and calcite cements (Luo et al. 2009). Hence, the porosity of hydrocarbon-saturated sandstones would be $12.5 \%$ (9.2\% (current thin-section porosity) $+3.3 \%$ (late cement volumes $)=12.5 \%$ ), thus providing a good quality reservoir for hydrocarbon migration and accumulation (Fig. 8).

\section{Conclusions}

(1) The Shaximiao sandstones in western Sichuan have undergone complex diagenetic modifications, including a moderate degree of compaction, cementation by authigenic quartz (early and late), calcite (early and late), and chlorite (grain-coating and porefilling), and dissolution.

(2) The point count data show that secondary pores (av. $5.5 \%)$ are more abundant than remaining primary pores (av. $3.7 \%$ ), and most of samples are dominated by secondary pores.

(3) Analysis of porosity evolution indicates that alteration of sandstones mainly occurred during two paragenetic stages (Stage I and Stage II). Mechanical compaction and cementation by early chlorite, calcite, and quartz typically decrease the depositional porosity (40.9\%) by an average of $37.2 \%$ leaving porosity of $3.7 \%$ after stage I $\left(<85{ }^{\circ} \mathrm{C}, 175-145 \mathrm{Ma}\right)$. The original intergranular porosity loss due to compaction is calculated to be $29.3 \%$, suggesting that mechanical compaction is the most significant diagenetic process in primary porosity destruction. Stage II can be further divided into two sub-stages (Stage $\mathrm{II}_{\mathrm{a}}$ and Stage $\mathrm{II}_{\mathrm{b}}$ ). During stage $\mathrm{II}_{\mathrm{a}}\left(85-120{ }^{\circ} \mathrm{C}, 145-125 \mathrm{Ma}\right)$, acidic fluids generated by the thermal maturation of organic matter in $\mathrm{T}_{3} x^{5}$ source rocks flowed into the Shaximiao sandstones and resulted in dissolution of feldspar and rock fragments, which enhanced porosity by $8.8 \%$, and the porosity after this stage increased from $3.7 \%$ to $12.5 \%$. During stage $\mathrm{II}_{\mathrm{b}}\left(>120{ }^{\circ} \mathrm{C}, 125-0 \mathrm{Ma}\right)$, the precipitation of late chlorite, calcite, quartz, and kaolinite destroyed $3.3 \%$ porosity, leaving porosity of $9.2 \%$ in the rock today.

Acknowledgments This work was financially supported by the National Science Foundation of China (No. 41172119) and the Important National Science \& Technology Specific Project (2011ZX05002-004001). The authors acknowledge China Petroleum \& Chemical Corporation (Sinopec) for permission to publish this paper.

Open Access This article is distributed under the terms of the Creative Commons Attribution License which permits any use, distribution, and reproduction in any medium, provided the original author(s) and the source are credited.

\section{References}

Ajdukiewicz JM, Lander RH. Sandstone reservoir quality prediction: the state of the art. AAPG Bull. 2010;94(8):1083-91.

Beard DC, Weyl PK. Influence of texture on porosity and permeability of unconsolidated sand. AAPG Bull. 1973;57(2):349-69.

Bjørlykke K, Jahren J. Open or closed geochemical systems during diagenesis in sedimentary basins: constraints on mass transfer during diagenesis and the prediction of porosity in sandstone and carbonate reservoirs. AAPG Bull. 2012;96(12):2193-214.

Bloch S, McGowen JH. Influence of depositional environment on reservoir quality prediction. In: Wilson $\mathrm{MD}$, editor. reservoir quality assessment and prediction in clastic rocks, vol. 30. Tulsa: SEPM Short Course; 1994. p. 41-57.

Cai KP, Liao SM. A research on the gas source of Jurassic gas reservoirs in western Sichuan Basin. Nat Gas Ind. 2000;20(1):36-41 (in Chinese).

Dai JY, Zhang YW, Xiong QH, et al. Effects of diagenesis on reservoir property and quality, a case study of the Cainan Oilfield in the east of Zhun Ga'er Basin. Pet Explor Dev. 2003;30(4):54-5 (in Chinese).

Ehrenberg SN. Measuring sandstone compaction from modal analysis of thin sections: how to do it and what the results mean. J Sediment Res. 1995;65A(2):369-79.

Ehrenberg SN. Assessing the relative importance of compaction process and cementation to reduction of porosity in sandstones; discussion; compaction and porosity evolution of Pliocene sandstones, Ventura Basin, California: discussion. AAPG Bull. 1989;73(10):1274-6.

Friedman I, O'Neil JR. Compilation of stable isotopic fractionation factors of geochemical interest. Reston: US Geological Survey Professional Paper; 1977. 
Gabitov RI, Watson EB, Sadekov A. Oxygen isotope fractionation between calcite and fluid as a function of growth rate and temperature: an in situ study. Chem Geol. 2012;306-307:92-102.

Gu XD, Liu XH. Stratigraphy in the Sichuan Basin. Wuhan: China University of Geosciences Press; 1997 (in Chinese).

Houseknecht DW. Assessing the relative importance of compaction processes and cementation to reduction of porosity in sandstones. AAPG Bull. 1987;71(6):633-42.

Li W, Zhao KB, Liu CX. Hydrogeology study of petroliferous basins. Beijing: Geological Publishing House; 2008. p. 179-83 (in Chinese).

Liu DL, Tao SZ, Zhang BM. Application and questions about ascertaining oil-gas pools age with inclusion. Nat Gas Geosci. 2005;16(1):16-9 (in Chinese).

Liu MJ, Liu ZS, Xiao M, et al. Paleoporosity and critical porosity in the accumulation period and their impacts on hydrocarbon accumulation - a case study of the middle $\mathrm{Es}_{3}$ member of the Paleogene Formation in the Niuzhuang Sag, Dongying Depression, Southeastern Bohai Bay Basin, East China. Pet Sci. 2014;11(4):495-507.

Lu HZ, Guo DJ. Progress and trends of researches on fluid inclusions. Geol Rev. 2000;46(4):385-92 (in Chinese).

Luo JL, Morad S, Salem A, et al. Impact of diagenesis on reservoirquality evolution in fluvial and lacustrine-deltaic sandstones: evidence from Jurassic and Triassic sandstones from the Ordos basin, China. J Pet Geol. 2009;32(1):79-102.

Lü ZX, Ye SJ, Qing C. Characteristics and evaluation of the upper reservoir of Shaximiao Formation in Xiaoquan gas field in west Sichuan. Nat Gas Ind. 2000;20(5):15-8 (in Chinese).

Marfil R, Rossi C, Lozano RP. Quartz cementation in Cretaceous and Jurassic reservoir sandstones from the Salam oil field, Western Desert, Egypt: constraints on temperature and timing of formation from fluid inclusions. In: Worden RH, Morad S, et al., editors. Quartz cementation in sandstones., Special Publication Number 29 of the International Association of SedimentologistsOxford: Blackwell Science; 2000. p. 163-82.

Meng QR, Wan E, Hu JM. Mesozoic sedimentary evolution of the northwest Sichuan Basin: implication for continued clockwise rotation of the South China block. Geol Soc Am Bull. 2005;117(3-4):396-410.

Prodanović M, Bryant SL, Davis JS. Numerical simulation of diagenetic alteration and its effect on residual gas in tight gas sandstones. Transp Porous Media. 2013;96(1):39-62.

Qin SF, Dai JX, Wang LS. Different origins of natural gas in secondary gas pool in western Sichuan foreland basin. Geochimica. 2007;36(4):368-74 (in Chinese).

Shen ZM, Gong YJ, Liu SB, et al. A discussion on genesis of the Upper Triassic Xujiahe Formation water in Xinchang area, western Sichuan depression. Geol Rev. 2010;56(1):82-8 (in Chinese).
Shen ZM, Liu T, Lü ZX, et al. A comparison study on the gas source of Jurassic natural gas in the western Sichuan depression. Geol J China Univ. 2008;14(4):577-82 (in Chinese).

Shen ZM, Liu Y, Liu SB. Denudation recovery of Himalayan periods in middle section of western Sichuan depression. Comput Tech Geophys Geochem Explor. 2011;33(2):189 (in Chinese).

Stroker TM, Harris NB, Elliott WC, et al. Diagenesis of a tight gas sand reservoir: upper cretaceous mesa verde group, Piceance Basin, Colorado. Mar Pet Geol. 2013;40:48-68.

Sweeney JJ, Burnham AK. Evaluation of a simple model of vitrinite reflectance based on chemical kinetics. AAPG Bull. 1990;74:1559-70.

Tan WC, Hou MC, Dong GY, et al. Research on depositional system of Middle Jurassic Shaximiao Formation in western Sichuan foreland basin. J East China Inst Technol. 2008;31(4):336-43 (in Chinese).

Taylor KG, Gawthorpe RL, Pannon-Howell S. Basin-scale diagenetic alteration of shoreface sandstone in the Upper Cretaceous Spring Canyon and Aberdeen Members, Blackhawk Formation, Book Cliffs, Utah. Sediment Geol. 2004;172(1-2):99-115.

Taylor TR, Giles MR, Hathon LA, et al. Sandstone diagenesis and reservoir quality prediction: models, myths, and reality. AAPG Bulletin. 2010;94(8):1093-132.

Wang DY, Wang J. Sedimentary facies and its distribution of the Middle Jurassic Shaximiao Formation in the West Sichuan Foreland Basin. Acta Geol Sichuan. 2010;30(3):255-9 (in Chinese).

Wood JR, Byres AP. Alteration and emerging methodologies in geochemical and empirical modeling. In: Wilson MD, editor. Reservoir quality assessment and prediction in clastic rocks, vol. 30. Tulsa: SEPM Short Course; 1994. p. 395-400.

$\mathrm{Xu} \mathrm{XS,} \mathrm{Liu} \mathrm{BJ,} \mathrm{Zhao} \mathrm{YG,} \mathrm{et} \mathrm{al.} \mathrm{Sequence} \mathrm{stratigraphy} \mathrm{and} \mathrm{basin-}$ mountain transformation in the western margin of upper Yangtze landmass during the Permian to Triassic. Beijing: Geological Publishing House; 1997 (in Chinese).

Yang KM, Zhu HQ, Ye J, et al. The geological characteristics of tight sandstone gas reservoirs in West Sichuan Basin. Beijing: Science Press; 2012 (in Chinese).

Ye SJ, Lü ZX. Reservoir characterization and factors influencing reservoir characteristics of the lower Shaximiao Formation in Xinchang gas field, western Sichuan. J Mineral Petrol. 2010;30(3):96-104 (in Chinese).

Zhang JL, Zhang PH, Xie J, et al. Diagenesis of clastic reservoirs: advances and prospects. Adv Earth Sci. 2013;28(9):957-67 (in Chinese).

Zhang L, Chen ZY, Nie ZL, et al. Correlation between $\delta^{18} \mathrm{O}$ in precipitation and surface air temperature on different time-scale in China. Nucl Tech. 2008;31(9):715-20 (in Chinese).

Zheng YF. On the theoretical calculations of oxygen isotope fractionation factors for carbonate-water systems. Geochem J. 2011;45(4):341-54. 